\title{
A FAMILY AND COMMUNITY APPROACH TO STEALING
}

\author{
KAY INGAMELLS \\ DAVID EPSTON \\ Unitec Institute of Technology, Auckland, New Zealand
}

\begin{abstract}
Stealing, a common problem of childhood and adolescence, is often regarded as an expression of distress and is associated with parental "distance" and family breakups, especially in older children (Patterson 1982, p. 263). This article tells the story of family therapy work with a New Zealand Indian family whose son's stealing habit followed the family from India to their new life in New Zealand. It illustrates a family and community approach to stealing developed by David Epston and Fred Seymour (Epston \& Seymour, 2008; Seymour \& Epston, 1992). Detailed accounts of therapy are relatively rare in the literature on conduct problems (Hawes, 2011, p. 410).
\end{abstract}

Regarded as an expression of conduct disorder or as an anti-social behavior (Miller \& Moncher, 1988), the problem of stealing has mostly been addressed alongside other problem behaviors (Sanders \& Markie-Dadds, 1992) through family interventions (Moore \& Patterson, 2003; Morawska \& Sanders, 2006; O’Dell, 1974 as cited in McPhail, 2008), or family-based treatments (Henggeler \& Sheidow, 2012). As a covert behavior, stealing has proven more difficult to address through behavioral methods than overt behaviors (Hinshaw, 2005; Pawsey, 1996; Venning, Blampied, $\&$ France, 2003). A difficulty has been that the problem is often suspected but only sometimes evident (Miller \& Moncher, 1988; Venning et al., 2003), and selfreporting even with overt behaviours is not reliable until at least age ten (Tremblay, 2010). The young person knows that they will not always be caught so behavioral strategies can be applied only when the stealing is evidenced. Dealing with the problem comprehensively requires being able to address instances when stealing is suspected as well as proven (Miller \& Moncher, 1988; Miller \& Klungness, 1989; Pawsey, 1996). This story of practice applying Seymour and Epston's previously researched approach based on 45 cases of stealing problems (Epston \& Seymour, 2008; Seymour \& Epston, 1992) originates from the rich tradition of collective

David Epston was the supervisor for work with this family and co-wrote the story presented in this article. Address correspondence to Kay Ingamells, Unitec Institute of Technology, Ratanui St. Hendersen, Auckland, New Zealand. E-mail: kingamells@unitec.ac.nz 
narrative practice (Denborough, 2008). It is the problem rather than the person that is worked upon and important others are gathered around the person to support the re-storying and re-claiming of identity (White \& Epston, 1990). Externalization of the problem, even subtly, allows the problem to become a resource to be played with rather than an obstacle to surmount (Freeman, Epston, \& Lobovits, 1997). The difficulties of working with such a covert problem can be playfully addressed within a narrative approach by turning the problem on its head. The covert nature of the problem is exchanged for covert "honesty tests" secretly set on behalf of the young person's moral re-identification as an "honest person." He/she volunteers to place him/herself in a position to be tested for their honesty. It is honesty rather than dishonesty, the preferred story rather than the problem story (White \& Epston, 1990) that is investigated. The character of the problem is used against itself as the random, covert nature of the tests mirrors the random, covert problem and so plays the problem at its own game.

Rather than the need for stealing to be discovered or suspicions taken into account, it is the audience of parents and allies, and their collective responses, that take center stage. This remedy unites the young person, his/her family, and victims of thefts in redeeming the young person's moral reputation. It also restores the dignity of his/her family.

Venning, Blampied, and France (2003) describe Epston and Seymour's honesty tests as "components designed to change parent and child attributions about stealing, and temptation-resistance training" (2003, p. 33). Such a reduction of this approach to "components" misses the point. Honesty tests serve to put an end to stealing as part of a re-storying of identity; they do not "train" either parent or child. Familial change takes place through speaking gently to the origins of the problem and inviting the family to come together against the stealing problem rather than locating the problem as a feature of the child's or the parents' behavior.

As only a small proportion of the theft undertaken by young people is aggressive (Baker, 1979; Belsen, 1975; Weger, 1985 as cited in Miller \& Moncher, 1988), it is not clear why theft is aggregated for study and treatment with aggressive behaviors (Tremblay, 2010, p. 352). This aggregation may occur simply because theft has been defined as a conduct disorder or antisocial behavior. The approach described in this article is unusual in responding to the stealing as stealing.

Epston and Seymour's approach, and other approaches that do not take place within a wider program of parenting training, have been described as difficult for parents who "lack general child-management skills" (Venning et al., 2003, p. 34). This view is not borne out by Epston and Seymour's research (Seymour \& Epston, 1992). Given the careful involvement of family and community within the latter, Venning's view does not seem defensible. Since some therapist involvement has been shown to be more effective than self-directed change (Morawska \& Sanders, 2006; Hawes, 2011), and reviews of studies strongly support "a multi-determined ecological conceptualization of adolescent antisocial behaviour" (Henggeler \& Sheidow, 2012, p. 33), Epston and Seymour's approach seems fitting. 
It is recommended that practitioners intending to embark on a similar family and community approach to stealing read this story of practice together with Epston and Seymour (2008) and Seymour and Epston (1992). ${ }^{1}$ It is intended that the approach can be "taught" mostly through the story. Occasional additional points are made in footnotes and there are footnotes to direct practitioners to the relevant sections of the 2008 companion article.

The story is taken faithfully from audio recordings of each session backed up by detailed notes. The family members were invited to contribute and they have verified this story as an accurate account of our work together. However, the version of the story presented in this article has been edited significantly to meet the requirements of Journal of Systemic Therapies. The full version is available at www.narrativeapproaches.com.

\section{OUR FIRST MEETING: STEALING A PASSAGE HOME}

What I most remember about my first meeting with 12-year-old Dilip was the tender sadness of his deep brown eyes. He was accompanied by his graceful and dignified mother, Sangita. Sangita had explained to me on the phone that she was desperately worried about her son who had been stealing for some years from family members and shopkeepers. More recently the stealing and lying had spread to friends' houses and to school. ${ }^{2}$

Dilip's intelligence was clear in everything he $\mathrm{did} .{ }^{3} \mathrm{He}$ had recently helped draw up plans for his mother's projects on her architectural design course, including 3-D movies and elevations. Sangita proudly told me how he had set up his own business repairing electrical items from "inorganic rubbish collections" then successfully selling them online to raise money for his family in hard times. She told me how she and her husband Kulwinder would lie awake contemplating how Dilip's entrepreneurial abilities might take him in the "wrong" direction in life and how his prodigious intelligence might be put to ill use. They were worried that one day they might "see him behind bars."

As I looked into this young man's eyes I saw a vulnerable innocent—not an enterprising entrepreneur with a dubious life ahead of him. Sangita's voice became strained as she related to me how Dilip's brother, Harman, had been diagnosed with leukaemia five years previously and was now in remission. She spoke carefully and softly with the matter of fact-ness of someone for whom devastating events have

\footnotetext{
${ }^{1}$ The book that contains the 2008 chapter can be downloaded for free from www.narrativeapproaches. com.

${ }^{2}$ Two studies have shown that theft increases from 10 years of age and continues to do so into early adulthood (Tremblay, 2010).

${ }^{3}$ Stealing increases with cognitive ability and opportunity (Tremblay, 2010).

${ }^{4}$ There is an association between stealing and future police involvement (Patterson, 1982 as cited in Miller \& Moncher, 1988).
} 
become routine. She told me how they had only been told of the diagnosis shortly after they arrived in New Zealand to start a new life. Kulwinder and Sangita had taken Harman with them, ahead of the other children who were to remain in India until their parents had settled and had applied to become New Zealand residents. Dilip remained with Sangita's in-laws and, because they had room for only one child, Dilip's younger sister Ravi went to live with family friends nearby.

Sangita leaned forward as if struggling to hold the weight of her story. She told me how she had returned to India to visit Dilip and Ravi. No sooner had her feet touched Indian soil when Kulwinder phoned her from New Zealand and broke the desperate news that Harman had a severe form of leukemia that had already spread to $98 \%$ of his body.

Faced with the knowledge that Harman was unable to receive the treatment that he desperately required in India, Sangita and Kulwinder made the difficult choice that they should remain in New Zealand with him. Torn between her children, Sangita was given a visa to return while their residency application, already delayed for a year, was being processed. She returned to New Zealand, little knowing that it would be more than two painful years before the family would be reunited. As nonresidents, their medical expenses were not covered. To pay for Harman's treatment they had to draw upon their savings and that of many of their family members back home, running up bills of half a million dollars.

Somewhat shaken by Sangita's story, I silently acknowledged her pain. I realized I must turn my attention to Dilip and the impact of his mother's account. In his eyes, if not in mine, the stealing problem would have center stage. Aware of Dilip's nervousness and the likely embarrassment that the problem had brought him, I was quick to externalize the apparent problem and to say lightly:5 "Dilip, your mum tells me she has been worried because she thinks a stealing problem has been trying to take over your life. That is why she has asked us to meet. Is that what you thought too?" Dilip's reply was barely audible.

I gently enquired when the stealing problem had first come along and how it had made its presence felt. He said that it had begun when he was five during the time he had been left behind in India, anticipating his reunion with his absent family. Speaking through her tears, Sangita told me:

He was not sure we would call him back. He was angry because twice we had to cancel his return because of Harman's illness and problems with the visa. Many times Kulwinder called him because our relatives said that he was bullying other kids. Even the bus driver was not willing to take him in his school bus. When Kulwinder called him Dilip was not saying anything. His father was angry that every day we were counting each dollar because Harman's treatment was so expensive and Dilip didn't speak when we called. Kulwinder said that it was not worth phoning him anymore. We had been

${ }^{5}$ Parents too are often reluctant to address stealing because of the shame of the problem for the child and for the family (Miller \& Moncher, 1988). This approach allows the stigma and shame attached to this problem to be mostly sidestepped. 
telling Dilip that he would be coming soon but in the last few months he lost patience and said "every time I pack my bags nothing happens. I will only believe I am coming to New Zealand when I am on the plane." Our family in India had a servant who had known Dilip from birth. One day he called me and ordered me to "come here and take this child or pack up and come back to India." It was a very bad time for all of us.

I asked, "Did he have some idea of what was going on in Dilip's heart?" "Yes," she replied. "Would he have said that his heart was breaking?" Tears began to form. I asked, "Dilip, was your five, six, or seven year old heart breaking?" "Yes," he replied. "Was it heart-breaking for your mum and dad that your heart was breaking?" Sangita began to sob. "Have you talked about these matters like this before?" I inquired. "Never," she choked out through her tears. "Had your family's heart been breaking in that time? Not just your heart and Dilip's heart but your husband's heart and perhaps your daughter's heart?" "Yes," Sangita replied.

I noticed that Dilip was sitting uncomfortably on the edge of his seat. I asked him if he would prefer to speak with me alone. Before I did so Sangita swiftly looked at her son and said, "He wants me to sit outside." She discreetly left the room.

To lighten the sadness that had fallen upon us, I wondered aloud: "Is this stealing problem an international stealing problem that has followed you across continents?" The corners of Dilip's mouth rose slightly. "Did you know?" I enquired,

that, in all the time I have talked with young people about the problems that have bothered them, I have discovered that sometimes problems start out trying to be helpful and only later become troublesome? Did the stealing try to help with the sadness of being left behind in India and the sadness for your brother in his illness?

Dilip replied, "Yes, maybe it took the sadness away a bit." Alarm crossed his face and tears filled his eyes as he said "I wasn't sure they would call me back." I asked, "Do you mean that you didn't know whether or not you would ever be called back to live with your family again in New Zealand?" Dilip nodded. "Dilip, does anybody know just how sad you have been?" Dilip shook his head. "No one knows. I don't want my family to be sad." 6

Realizing that this sadness was at the heart of the problem but also knowing that I must tread carefully, I gently asked: "Dilip, would you mind if I try to understand a little more about this sadness?" He hesitated but then nodded his approval. "Could I start by asking you how big the sadness has been?" He looked a little confused. I continued:

If we could measure the sadness [Epston, 1986], and let's say the most sadness there could ever be is the width of this room which is, oh, about three meters, how much sadness was there in India when you feared they wouldn't call you to live with them in New Zealand? 
"Two meters." Dilip replied with considerable certainty. "And how much sadness is there now here in New Zealand?" It turned out that now there was one meter of sadness remaining. Dilip told me that the remaining sadness came from missing the family he had left behind in India. Sensing that our conversation might be overwhelming him, I asked him if he thought it was time to welcome his mother back into the room. He nodded, adding: "But I don't want to talk about what happened." Aware that the sadness was key if Dilip and his family were to be rescued from the effects of his stealing reputation, but also mindful of the need to honor Dilip's tenderness, I asked him if I could briefly mention that we had talked about his life in India and how the stealing had come about. He nodded. Could I also mention the sadness and how it had become less since he had been reunited with his family? Dilip nodded.

Sangita came into the room hesitantly. I pondered how much hope she had pinned on the time I had spent alone with Dilip. "Sangita, Dilip and I have been talking about his time away from you and how the stealing began. He felt very sad while he was without you but, since his return, the sadness is much less." I saw Sangita's tears begin. The sadness was palpable.

"Sangita, have you talked together as a family about all that has happened to Harman and to each of you?" Dilip's eyes widened in what suggested to me renewed alarm. "No, not even Kulwinder and I have talked." I asked, "Has this ordeal left little room or time for really feeling or really talking?" "Yes," she replied:

Every year something big is happening. When I was saying goodbye to my brotherin-law at the airport last week, he said, 'In your life it is always headlines, not small news.' When Harman got sick we were alone here. There has been no time to talk.

Contemplating the way forwards, I felt unable to venture further into the territory of their sadness. To do so would have been to trespass into their pain when there were other routes available. I asked, "If we were to find a way to try to put the sadness to rest without talking about it directly, could that be helpful?" Sangita and Dilip nodded. "How are you hoping that our conversations together might help Dilip and your family?" I enquired. Sangita gazed at me then said, as if uttering a prayer, "we want to know him better again. I would like the sadness not to come into his life again. I would like him to be happy."

\section{OUR SECOND MEETING: HONESTY AS A WAY THROUGH SADNESS}

A week later, with Dilip's and Sangita's permission, I summarized for Kulwinder our previous conversation. I proposed that while talking might be one way, there are other ways to tend to wounds. Turning to Dilip, I asked, "Am I right in thinking that your family's suffering makes you suffer?" He nodded. "May I speak a little about your suffering as I understand it?" They all nodded. 
This family has endured much. Many people have told me that when there is too much suffering, they come to believe it is better not to talk about it. Instead, they decide to get on as best they can with their lives. They say that has worked for them for a while. But then they tell me that the sadness catches up with them: it can reach them in the strangest ways. I am not sure about this, but could the stealing have been a way to draw others to your suffering? It is a measure of this family's wonderful dignity and endurance that you have not cracked under the pressure. Dilip, you are a very young man and I think you can help your family out of their sorrow. I know usually we turn to the eldest not the youngest but you are different. You have talents which show you are a quick learner. What you can do_-and we all will help you-is to prove once and for all, beyond a shadow of doubt, that you are an honest boy, son, and man to be. ${ }^{7}$ When you prove this, I will ask your family to show you their happiness and, when you think people are happy enough, then, and only then, we will talk about the sadness. Then we will see how everyone can be together in sickness and in health as a wonderful family that has suffered. And, Dilip, you will always know when you grow up that it was you who led the way from sadness to happiness for a family who has had more sorrow than almost any other I have known.

Turning to Dilip, I addressed him alone:

Dilip, I am going to suggest a way of restoring your reputation as an honest person. You won't need to talk about your feelings right now. Would you be interested in such a way, even if I were to tell you that for it to work I cannot reveal to you exactly what it involves and you will only discover this over time? ${ }^{8}$

Surprised, Dilip looked towards me, a shy enthusiasm for the project on his face. He nodded. I say, "This is an idea that has worked many, many times before. Do you trust me that I have a way to prove that you are either a stealer or an honest boy?" Dilip mouthed a silent "yes." I add, "I cannot give you all the details now, but next week we can begin. Today, could you help me understand more about the stealing and the reputation it has left you with?"

After agreement, I say, "Now, to begin, I need to know: who cares whether you are an honest boy or a stealer?"9 Dilip's mother replied, "Well, his grandmother. She cares for him very much." Then to Dilip she added: "And your uncle, my sister, your brother, and your teacher." "And his grandparents and my father in particular" ventured Kulwinder. "And Arthur and Julie" added Sangita. "Who are Arthur and Julie?" I enquired. "Arthur," Sangita replied,

is an elderly man who is a friend of the family. He is very fond of Dilip and Dilip is very fond of him. Arthur lets Dilip spend time with him in his workshop, he shows him how to use tools and make all sorts of things. Daniel is Dilip's school friend and

${ }^{7}$ The focus is upon honesty and restoration of pride rather than dishonesty and shame.

${ }^{8}$ The restoration of an honest reputation is proposed in place of the refutation of stealing (Epston \& Seymour, 2008, p. 141).

${ }^{9} \mathrm{~A}$ community is recruited for the restoration of honesty (Epston \& Seymour, 2008, p. 144). 
Julie is his mother. Julie was the first person who talked to us about the stealing in New Zealand. She carries a loving heart. She didn't want to punish him. I ask, "Dilip, how has the stealing affected these people who care about you?"10

Kulwinder answered: "My parents love him very much and you know what it is like when a loved one is not on the right path. My father is especially worried." I ask, "Dilip, what do you think the effects will be upon the people who care for you when they find out that, beyond a shadow of a doubt, you are now an honest boy? Can we start with your Granddad?"11

Dilip looked surprised by my question but seemed to be sticking with it. I offered a question to scaffold his response: "When he finds out, will he call on the phone or send you an email? What will he say?" "He will be happy," Dilip said shyly. I asked him a question closer to home: "Do you have any idea what a reputation for honesty would mean to your parents?" Dilip replied, "It would bring peace and happiness to their hearts." Sangita, tears in her eyes, replied to my question:

We love him very much. Knowing that Dilip is an honest boy would be the biggest gift to us. It will take time for us to know if he becomes honest again. We have to be sure his honesty is real.

\section{OUR THIRD MEETING: THE IDEA IS REVEALED}

"Dilip, as I said, this is a tried and tested way for you to prove that you have regained your honesty. Are you sure you want to go ahead?" Dilip nodded hard. "Okay, I am going to propose that you are honesty tested." The family looked at me quizzically.

Dilip, as these are tests, I cannot tell you the details because if I did it would mean you were not being tested. Your parents will decide how long the tests will take-it could be weeks or months - to satisfy them that you are honest. When the time comes, when you have proven beyond a shadow of doubt that you have redeemed your reputation as an honest young man we will hold an honesty party to celebrate. Now, if you are sure you wish to go ahead with the honesty testing, let us shake hands to confirm our trust in one another. ${ }^{12}$

Dilip dutifully placed his hand in mine: the deal was sealed. ${ }^{13}$ "Dilip, now I am going to meet privately with your parents to let them know what this challenge to restore your honesty involves. Then you and I have a letter to write."

After Dilip had left the room I outlined for his parents how we might set the honesty tests. ${ }^{14}$ "Over the next few weeks or months, you will set Dilip tests which will

\footnotetext{
${ }^{10}$ The effects of the stealing reputation on relationships are established (Epston \& Seymour, 2008, p. 142).

${ }^{11}$ The effects of an honest reputation being restored, versus the effects of stealing, are explored.

${ }^{12} \mathrm{An}$ expression of trust is given in place of the suspicion brought by the problem.

${ }^{13}$ Consent is given for honesty testing to restore an honest reputation (Epston \& Seymour, 2008, p. 149).

${ }^{14}$ See Epston and Seymour (2008, p. 150) on setting up the process of honesty testing.
} 
confirm him as either an honest boy or a stealer. These must be carefully planned so that he has no idea they are tests." We then spoke for some time about examples of tests other families had set in the past, the importance of their unpredictability, varying of location, the involvement of Dilip's supporters, the duration of the tests and a further period of probation during which they could confirm that Dilip had restored his honesty. ${ }^{15}$

Kulwinder and Sangita decided on a period of three to four months during which Dilip would have to face the challenge of six tests followed by a probation period of three to four weeks. I explained that it is vital to the success of the tests that others who care for their son are enrolled as witnesses. To that end, I would assist Dilip to write a letter in which he would formally disavow his stealing habit and declare in writing how he wished to renew his honesty. Dilip would be expected to email this letter to the concerned parties or read it to them over the phone. Immediately after each test Dilip would be required to call or contact each person on his "honesty team" to declare the result revealed to him by his parents.

Dilip returned, and we slowly and carefully crafted a letter to send to his honesty supporters. We composed the letter by way of an extended enquiry that was continually interrupted so I could write down his answers. ${ }^{16}$

\section{OUR FOURTH MEETING: ELEVENTH HOUR CONFESSIONS AND THE RESTORATION OF PRIDE AND HONOR}

We met again in a week. "How did you get on with the letters, Sangita?" I asked. Sangita replied:

There was only one problem. He didn't want to give the letter to Arthur. He actually cried the night before Arthur was due to come with a pet rabbit for him. I said, "You have to tell him or you won't be going to his house." The next morning he said that he would give him the letter. He gave it as Arthur was leaving; it was hard for him but he did it.

I asked, "And how did the other people whose support Dilip called upon respond?" Sangita was quick to reply that, when Dilip had bravely read his letter to them on the phone, her father and mother had said they would be very happy if the stealing went away and they would show their happiness in the form of a large gift for him when he passed all the honesty tests. She said that they had already begun the honesty tests and so far Dilip had passed two tests with flying colors. Their confidence in him was palpable. I flung out my hand to meet Dilip's in a "high five." "Great. Great, fantastic!" Seizing the moment, I asked, "Are you feeling the

\footnotetext{
${ }^{15}$ Miller \& Moncher (1988, p.75) note the importance of all adults having the same definition of stealing so that all acts of stealing can be addressed. Unity is provided more easily in this approach by shifting the focus to an understanding of and evidence for honesty.

${ }^{16}$ Co-crafting of letters (Epston \& Seymour, 2008, p. 146).
} 
effects of having a more honest reputation?" "Yes," he replied confidently. "And tell me, how would you say having a more honest reputation has affected you?" Dilip's reply surprised me:

Well, I am allowed in the garage now. I haven't been allowed in there for a while which was really hard because that's where I make things. My parents said I couldn't go in there because of the stealing. Now I am making a steamboat out of oil cans. Arthur has lent me a soldering iron.

I said, "Okay, would it be fair to say that your honest reputation is winning back your parents' trust in you?" Dilip's expression said it all as he shot a shy smile at his parents whose faces were already alight with pleasure. I asked, "What's it like for you to know that your parents' trust in you is growing as your reputation for honesty is growing?" Dilip replied that it was good. Eager to capitalize on the growing trust by naming the pride on all their faces, I asked "Are you feeling a little bit more proud of yourself?" "YEAH." Comparing the present pride with the sadness of our first meeting, I asked him to measure the pride: "How proud? I mean if you were to show me how much pride you have now, how much would it be? If you were to stretch your arms out and show me, how much would it be?" Dilip's arms shot away from his side as his hands stretched across the room. "And how much did you have before?" In response, his hand shrank back to about 1/3 of their previous expanse. "What is it like to have that much more pride?" "Good. It feels good."

"We are so pleased and relieved" said Kulwinder. "We are very proud of him. It feels as if one worry is ending. It brings us happiness." "Dilip," I asked, "What is it like to hear that you are bringing your parents happiness and that they have one less worry?" "Good." I asked, "And did you know that they are extremely proud of you. Did you know that?" "No," he said, with a hint of surprise.

\section{OUR FIFTH MEETING: SADNESS GIVES WAY}

Our next meeting was scheduled for a month later, with the proviso that they could call me at any time if they needed any help. Not having heard from them, I was not surprised when the family entered my room smiling. Sure enough, Dilip's honesty had been subjected to four more tests: money was left in the shopping bags he was asked to unpack, coins were left in the pockets of the laundry he was asked to put in the machine, a box of chocolates was left in the kitchen cupboard, and when Sangita's brother-in-law came to stay, he left some coins and notes for Dilip to find when he took Dilip away in the school holidays.

Sangita described how the developments had "filled her with joy." Dilip had dutifully called or contacted each of his supporters after he had passed each honesty test. His uncle in India had said that it was great news and he should "keep it up." His Grandparents had revealed how they no longer feared that he "might not be honest when he grew up." 
When I enquired about the relative size of his reputation for stealing compared to his growing reputation for honesty, Dilip announced that the stealing reputation, which had previously had $100 \%$ power, now had only $20 \%$. "He is not angry like he was either," said Sangita. "I had the feeling that he was angry with us for leaving him in India and he has been showing us his anger since he came here. But now the anger seems to have gone." "And," she continued, "his pride is helping him to eat more! He wasn't eating and now his pride is helping his appetite." This seemed an opportune moment to plan the "honesty party."17

\section{OUR SIXTH MEETING: THE HONESTY PARTY 18}

Sangita insisted that the party should take place at their home. We set the date to be six weeks away, to allow time for Dilip's honest reputation to prove its permanence, and together we wrote the invitation. With my help, Dilip and his father composed a speech to be read aloud at the honesty party.

The evening of the party came. A smiling Dilip greeted me. We were ushered into the large living room, greeted by Sangita, Kulwinder, Harman, and Ravi and every one of the people Dilip had invited. Mustering the dignity called for at important occasions, I began:

Welcome to Dilip's honesty party. As you all know, you are here because you have believed in Dilip and been willing to stand by his side whilst he proved that he is now an honest boy, honest son, and honest man to be. I would like to give each of you the opportunity to say something about how Dilip has restored his honesty. Who would like to begin?

Nervousness pervaded the room. Kulwinder rose to his feet:

We were so worried before and we did not know what to do. We felt so bad that Dilip had to be away from us for so long and then, just when we thought we had become a family again, the stealing and lying separated us even more. Sangita and I would talk in the night about our worries for Dilip's future.

Sangita, linking her arm in her husband's, said, "We are so proud of Dilip now. He has passed all his tests and so we have trust in him. We now know that he is honest and our hearts are light again." For a moment both parents held Dilip's gaze.

Kulwinder carefully pulled out of his pocket several emails from family in India. Addressing Dilip, he read his father's e-mail that spoke of the family's faith in Dilip and Sangita's parents made mention of the surprise "honesty" gift winging its way to Dilip. As Kulwinder sat down, Arthur coughed. Dilip's eyes turned to him. "Dilip, you can be very proud of your honesty. I know that you have had some hard times but I have always known that you were a good boy. I knew you could do it."

\footnotetext{
${ }^{17}$ Setting up the "honesty party" (Epston \& Seymour, 2008, p.151).

${ }^{18} \mathrm{An}$ example of providing audience for new stories (White, 2011).
} 
"Now Dilip, it is time for your speech." I announced. Eagerly he went to stand at the fireplace. He read the prepared speech with dignity:

I can't remember when the stealing began but it was around for about seven years. It began in India when I was living with my grandparents after my brother became ill and my mother and father had to leave me. The stealing problem was encouraged by the sadness of being apart from my family. It made my mum and dad sad. That made me sad. I wanted the stealing to stop and so did my mum and dad. My mum and dad decided to do something to help me and we went to see Kay. I decided I was going to regain my honest reputation. My parents, Kay, friends, and family helped me to regain my reputation by setting tests of my honesty. I passed all these tests with flying colors. My mum and dad helped me by setting the tests and by having faith in me. Julie and Arthur helped me by agreeing to have tests at their homes. Arthur helped me by telling me, when he read my letter saying how I wished to regain my reputation as an honest person, that 'the stealing is nothing to do with our relationship.' Now I have regained my reputation as an honest person. This has been good for me because my parents are less worried and they are happier. I am also happier. I want to thank everybody for their help. I am very proud to have regained my honest reputation.

When Dilip finished speaking he seemed to have stepped into a new self-assurance. Sangita ushered everyone into the dining room where a surprise feast awaited us.

A year later, I revisited them to read them a draft of this article and leave a copy with them. I sought any editing that they might want and their sanction to publish this on their behalf. As I read it to Sangita, tears rolled down her cheeks. "You know," she said through her tears,

we were not ready to believe that the stealing would stop so quickly but it did and it has not returned. Dilip always used to oppose us and he was always the last to be convinced of anything. Now he does his household chores without argument. His mind is now busy with new things like art and music. Entirely by himself he has learnt to play the piano. He is so focused and maybe this is why the stealing problem went so deep, maybe his focus was misdirected. In his heart he was really angry. I don't remember the last time we saw his anger. We have our son again.

\section{REFERENCES}

Denborough, D. (2008). Collective narrative practice. Adelaide, Australia: Dulwich Centre Publications.

Epston, D. (1986). Night watching: An approach to night fears. Dulwich Centre Review, 28-39.

Epston, D., \& Seymour, F. (2008). Community approaches-real and virtual-to stealing. In Epston, D. (Ed.), Down under \& up over: Travels with narrative therapy (pp. 139-156). London: Karnac Books.

Freeman, J., Epston, D., \& Lobovits, D. (1997) Playful approaches to serious problems: Narrative therapy with children and their families. New York: W.W. Norton. 
Hawes, D. J. (2011). Developmental perspectives on the treatment of childhood conduct problems. Pragmatic Case Studies in Psychotherapy, 7, 410-421.

Henggeler, S. W., \& Sheidow, A. J. (2012). Empirically supported family-based treatments for conduct disorder and delinquency in adolescents. Journal of Marital \& Family Therapy, 38, 30-58. doi:10.1111/j.1752-0606.2011.00244.x

Hinshaw, S. P. (2005). Objective assessment of covert anti-social behaviour: Predictive validity and ethical considerations. Ethics and Behavior, 15, 259-659.

McPhail, L. (2008). Early intervention for stealing: Interrupting the antisocial trajectory: A thesis submitted in fulfillment of the requirements for the degree of Master of Arts of Psychology in the University of Canterbury, New Zealand. Retrieved March 2, 2012, from http://hdl.handle.net/10092/1545

Miller, G. E., \& Klungness, L. (1989). Childhood theft: A comprehensive review of assessment and treatment. School Psychology Review, 18, 82-97.

Miller, G., \& Moncher, F. (1988). Critical issues in the assessment of childhood stealing behaviour. Advances in Behavioural Assessment of Children and Families, 4, 33-96.

Moore, K. J., \& Patterson, G. R. (2003) Parent training. In W. O’Donohoue, J. E. Fisher, \& S. C. Hayes (Eds), Cognitive behaviour therapy: Applying empirically supported techniques in your practice (280-287). New York: Wiley \& Sons.

Morawska, A., \& Sanders, M. R. (2006). Self-directed behavioural family intervention. International Journal of Behavioural Consultation and Therapy, 2, 332-340.

Patterson, G. (1982). Coercive family process. Eugene, OR: Castalia.

Pawsey, R. (1996) A family behavioural treatment of persistent juvenile theft. Australian Psychologist, 31, 28-33.

Sanders, M. R., \& Markie-Dadds, C. (1992). Towards a technology of prevention of disruptive behaviour disorders: The role of behavioural family intervention. Behaviour Change, 9, 186-200.

Seymour, F. W., \& Epston, D. (1992). An approach to childhood stealing with evaluation of 45 cases. In M. White \& D. Epston (Eds.), Experience, contradiction, narrative, and imagination: Selected papers of David Epston \& Michael White, 1989-1991 (pp. 189-206). Adelaide, Australia: Dulwich Centre Publications.

Tremblay, R. (2010). Developmental origins of disruptive behaviour problems: The 'original sin' hypothesis, epigenetics and their consequences for prevention. Journal of Child Psychology and Psychiatry, 51, 341-367.

Venning, H. B., Blampied, M., \& France, K. (2003). Effectiveness of a standard parentingskills program in reducing stealing and lying in two boys. Child \& Family Behaviour Therapy, 25, 31-44.

White, M. (2011). Narrative practice: Continuing the conversations. New York: W.W. Norton. White, M., \& Epston, D. (1990). Narrative means to therapeutic ends. New York: W. W. Norton. 
Copyright of Journal of Systemic Therapies is the property of Guilford Publications Inc. and its content may not be copied or emailed to multiple sites or posted to a listserv without the copyright holder's express written permission. However, users may print, download, or email articles for individual use. 